dopamine and 5-hydroxytryptamine afferents. Life Sci. 16, 733-743 (1976)

12) Nomura, Y. ANd Segawa, T.: Striatal dopamine content reduced in developing rats treated with 6-hydroxydopa. Japan. J. Pharmacol. 29, 306-309 (1979)

13) Nomura, Y., Kajiyama, H., NaKata, Y. and Segawa, T.: Muscarinic cholinergic binding in striatal and mesolimbic areas of the rat: Reduction by 6-hydroxydopa. Europ. $J$. Pharmacol. 58, 125-131 (1979)

14) Mason, S.T. ANd Fibiger, H.C.: Possible behavioral function for noradrenaline-acetylcholine interaction in the brain. Nature 277, 396-397 (1979)

\title{
HYPOTENSIVE EFFECT OF CAPTOPRIL, AN ANGIOTENSIN CONVERTING ENZYME INHIBITOR IN PENTOBARBITAL ANESTHETIZED DOGS
}

\author{
Susumu SATOH, Susumu FUJISAWA*, Reiko TANAKA* \\ and Kengo NAKAI* \\ Department of Pharmacology, Pharmaceutical Institute, Tohoku University, \\ Sendai 980, Japan and ${ }^{*}$ Department of Pharmacology, Akita University, \\ School of Medicine, Akita 010, Japan
}

Accepted September 28, 1979

The renin-angiotensin system probably plays a role in regulating blood pressure. The development of specific inhibitors of this system has contributed greatly to the present understanding of the physiological role of angiotensin in hypertension. D-3-mercapto-2D-methylpropanoyl-L-proline (captopril) was recently introduced as an orally active inhibitor of the enzyme that converts angiotensin I to angiotensin II (1-6). Enzyme inhibition with captopril is characterized by a diminution in the pressor response to angiotensin $I$ without a change in that to angiotensin II (3). Angiotensin converting enzyme also catalyzes the inactivation of kinins and is often referred to as kininase II (5). It has been reported that inhibition of angiotensin converting enzyme with captopril causes marked enhancement of the depressor effect of bradykinin $(7,8)$.

The present study was performed to evaluate the hypotensive effect of captopril in relation to plasma renin activity in pentobarbital anesthetized dogs.

Thirty-four mongrel dogs of either sex weighing from 9 to $16 \mathrm{~kg}$ were anesthetized with $30 \mathrm{mg} / \mathrm{kg}$ i.v. sodium pentobarbital. Decamethonium bromide $(0.25 \mathrm{mg} / \mathrm{kg}$, i.v.) was administered to provide skeletal muscle relaxation and to prevent active respiratory movement. All dogs were intubated and ventilated with a respirator. In experiments of renal arterial occlusion, one or both renal arteries were exposed through retroperitoneal incisions and adjustable clamps for occlusion were placed on the renal arteries. The renal blood flow was measured with a square-wave non-cannulating electromagnetic flowmeter. The brachial artery and cephalic vein were cannulated for measuring systemic blood pressure and for intravenous administration of drug solutions, respectively. For the measurement 
of plasma renin activity (PRA), five $\mathrm{ml}$ samples of arterial blood were withdrawn from the brachial artery. PRA was determined by radioimmunoassay using a kit (Dainabott). All samples were incubated at $37^{\circ} \mathrm{C}$ for $2 \mathrm{hr}$, and activity was expressed as $\mathrm{ng} / \mathrm{ml} / \mathrm{hr}$ angiotensin I equivalent. Angiotensin II (Hypertensin, CIBA) was dissolved in $0.9 \%$ saline, and captopril (Squibb) was dissolved in $0.1 \mathrm{M}$ phosphate buffer and adjusted to approximately pH 7 . To elicit a relatively higher and lower range of PRA, the following treatments were given to 3 groups of dogs. In addition an untreated group of dogs was studied. In 8 dogs, renal arterial occlusion was produced by tightening a clamp on one renal artery until blood flow was decreased by approximately $50 \%$ of the control value as previously reported (9). In 5 dogs, to decrease the PRA, both renal arteries were completely occluded with clamps. Another 7 dogs were given an intravenous infusion of angiotensin II. This procedure was reported to suppress PRA by virtue of a negative feed back mechanism (10). These treatments were performed throughout the experiments. In these treated groups, blood was sampled in the control period and during the treatment period. Then, $1 \mathrm{mg} / \mathrm{kg}$ of captopril was given i.v. immediately after the first blood sampling in the untreated group and after the second blood sampling in the treated groups, respectively. The mean systemic blood pressure gradually decreased and reached the lowest level within $10 \mathrm{~min}$ after the injection of captopril. Thus, this reduction in mean blood pressure was considered the maximum hypotensive effect of captopril.

All mean values and standard errors are shown in Table 1.

In 14 untreated dogs, PRA ranged between 4.9 to $26.3 \mathrm{ng} / \mathrm{ml} / \mathrm{hr}$, among $12 \mathrm{dogs}$, and two exceptional values of 0.8 and $56.5 \mathrm{ng} / \mathrm{ml} / \mathrm{hr}$, were obtained in 2 dogs. The hypotensive effect of captopril was $23.3 \pm 3.6 \mathrm{~mm} \mathrm{Hg}$ in this group.

In $8 \mathrm{dogs}$, PRA was $11.5 \pm 3.2 \mathrm{ng} / \mathrm{ml} / \mathrm{hr}$ in the control period prior to partial occlusion of the renal artery. Blood pressure gradually increased and reached a steady level during

TABLE 1. Mean values and standard errors of mean systemic blood pressure (BSP) and arterial plasma renin activity (PRA) in the control, during the period of treatments and after the intravenous administration of $1 \mathrm{mg} / \mathrm{kg}$ of captopril

\begin{tabular}{|c|c|c|c|c|c|c|}
\hline \multirow{2}{*}{$\begin{array}{l}\text { Treatments }^{\mathrm{a}} \\
\begin{array}{l}\text { Number of } \\
\text { dogs) }\end{array}\end{array}$} & \multicolumn{4}{|c|}{$\mathrm{SBP}(\mathrm{mm} \mathrm{Hg})$} & \multicolumn{2}{|c|}{ PRA (ng/ml/hr) } \\
\hline & Control & During $^{b}$ & After & $\Delta^{\mathrm{d}}$ & Control & During ${ }^{b}$ \\
\hline Untreated (14) & $121.4 \pm 4.5$ & & $98.1 \pm 6.2^{\mathrm{e}}$ & $23.3 \pm 3.6$ & $15.8 \pm 3.6$ & \\
\hline PO & $111.6 \pm 3.8$ & $124.8 \pm 3.0^{\mathrm{e}}$ & $95.1 \pm 3.8^{\mathrm{r}}$ & $30.0 \pm 1.9$ & $11.6 \pm 3.2$ & $29.7 \pm 3.5^{\mathrm{e}, \mathrm{g}}$ \\
\hline $\mathrm{CO}$ & $101.2 \pm 3.3$ & $104.2 \pm 10.0$ & $82.6 \pm 10.4^{f}$ & $21.6 \pm 3.0$ & $26.4 \pm 4.3 \mathrm{~g}$ & $13.8 \pm 1.4^{\mathrm{e}}$ \\
\hline Ang II & $110.9 \pm 6.2$ & $131.2 \pm 5.6^{\mathrm{e}}$ & $122.1 \pm 7.5$ & $5.3 \pm 1.0 \mathrm{~g}$ & $11.2 \pm 2.8$ & $4.7 \pm 1.3^{\mathrm{e}, \mathrm{g}}$ \\
\hline
\end{tabular}

a Partial occlusion of one renal artery (PO), complete occlusion of both renal arteries (CO) and intravenous infusion of $55 \mathrm{ng} / \mathrm{kg} / \mathrm{min}$ of angiotensin II (Ang II).

b Values during the period of 40 to $50 \mathrm{~min}$ in PO, 1 to $4 \mathrm{hr}$ in CO and 30 to $40 \mathrm{~min}$ in Ang II after beginning of treatments.

c Values of the lowest level of SBP within 10 min after the injection of captopril.

d Values of the hypotensive effect of captopril.

e Significantly different from control $(\mathrm{p}<0.02-0.001)$.

P Significantly different from the value during the period of treatment $(\mathrm{p}<0.01-0.001)$.

g Significantly different from the untreated group $(p<0.05-0.01)$. 
the period of 40 to $50 \mathrm{~min}$ after the start of the occlusion $(\mathrm{p}<0.01$, compared with the control). During this period, PRA was increased to $29.7 \pm 3.5 \mathrm{ng} / \mathrm{ml} / \mathrm{hr}(\mathrm{p}<0.001$, compared with the control and $\mathrm{p}<0.02$, compared with the untreated group). Captopril caused a hypotensive effect of $30.0 \pm 1.9 \mathrm{~mm} \mathrm{Hg}$ in this group.

In 5 dogs with a relatively higher level of PRA, $26.4 \pm 4.3 \mathrm{ng} / \mathrm{ml} / \mathrm{hr}(\mathrm{p}<0.05$, compared with the untreated group) in the control period, the complete occlusion of both renal arteries produced a reduction of PRA in all dogs during the period of 1 to $4 \mathrm{hr}$ after starting the occlusion ( $p<0.02$, compared with the control). However, the final level of PRA after total bilateral occlusion, $13.8 \pm 1.4 \mathrm{ng} / \mathrm{ml} / \mathrm{hr}$, was much the same as that in the untreated group. The injection of captopril had much the same hypotensive effect as that in the untreated group.

In the other $7 \mathrm{dogs}$, intravenous infusion of angiotensin II at the rate of $55 \mathrm{ng} / \mathrm{kg} / \mathrm{min}$ produced a steady level of blood pressure for 30 to $40 \mathrm{~min}$ after start of the infusion. During this period, the reduction of PRA was obtained in all dogs and the value of $4.7 \pm 1.3 \mathrm{ng} / \mathrm{ml} / \mathrm{hr}$ was reduced from that of $11.2 \pm 2.8 \mathrm{ng} / \mathrm{ml} / \mathrm{hr}$ in the control period $(\mathrm{p}<0.01$, compared with the control and $p<0.05$, compared with the untreated group). In accordance with the reduction of PRA, captopril reduced blood pressure by only $5.3 \pm 1.0 \mathrm{~mm} \mathrm{Hg}(\mathrm{p}<0.01$, compared with the untreated group).

In Fig. 1, the individual values for the hypotensive effect produced by captorpil and PRA obtained just before the injection of captopril are plotted. Calculation for the relationship between PRA and the hypotensive effect of captorpil showed a highly significant correlation coefficient $(\mathrm{r}=0.64, \mathrm{p}<0.001)$.

It is likely that a positive linear relationship exists between PRA and amounts of angio-

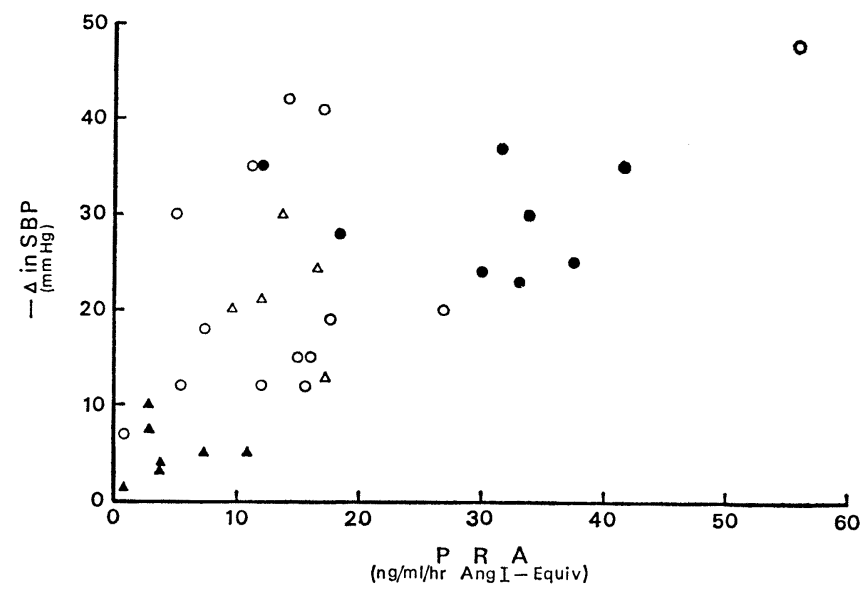

Fig. 1. Relation between the hypotensive effect of $1 \mathrm{mg} / \mathrm{kg}$ of captopril given intravenously ( $\triangle$ in SBP) and arterial plasma renin activity (PRA) before injection of captopril. Correlation coefficient is $0.64(\mathrm{p}<0.001)$. Different symbols refer to four groups of dogs: untreated $(O)$, partial occlusion of one renal artery $(\Theta)$, complete occlusion of both renal arteries $(\triangle)$ and intravenous infusion of angiotensin II (A), respectively. 
tensin II in plasma in the present experiment. Therefore, captopril might exert its hypotensive effect by preventing the formation of angiotensin II through the inhibition of angiotensin converting enzyme. However, the possibility of kinins contributing to the hypotensive effect of captopril remains unsettled. It has been reported that angiotensin II and kinin-like substances appear in the blood after reduction in renal blood flow in dogs (11). Therefore, it is probable that the interventions imposed in the present experiment may produce simultaneous increases in the amounts of both angiotensin II and kinins in the blood. Thus, it remains to be defined whether the hypotensive effect of captopril is exerted by the prevention of the formation of angiotensin II and/or by the accumulation of endogenous kinins.

\section{REFERENCES}

1) Cushman, D.W. AND Ondettr, M.A.: Design of active site-specific inhibitors of angiotensinconverting enzyme. Fedn. Proc. 36, 1049 (1977)

2) Laffan, R.J., Goldberg, M.E., High, J.P., Schaeffer, T.R., Waugh, M.H. and Rubin, B.: Antihypertensive activity of SQ 14,225, an orally active inhibitor of angiotensin converting enzyme. Fedn. Proc. 36, 1049 (1977)

3) Rubin, B., Laffan, R.J., Kotler, D.G., O’Keefe, E.H., DeMaio, D.A. and Goldberg, M.E.: Pharmacological properties of SQ 14,225 , an orally active specific inhibitor of angiotensin converting enzyme. Fedn. Proc. 36, 1049 (1977)

4) Ondetti, M.A., Rubin, B. ANd Cushman, D.W.: Design of specific inhibitors of angiotensinconverting enzyme: new class of orally active antihypertensive agents. Science 196, 441-444 (1977)

5) Laffan, R.J., Goldberg, M.E., High, J.P., Schaeffer, T.R., Waugh, M.H. and Rubin, B.: Antihypertensive activity in rats of SQ 14,225, an orally active inhibitor of angiotensin converting enzyme. J. Pharmacol. exp. Ther. 204, 281-288 (1978)

6) ERdös, E.C.: The angiotensin I converting enzyme. Fedn. Proc. 36, 1760-1765 (1977)

7) Murthy, V.S., Waldron, T.L., Goldberg, M.E. AND Vollmer, R.R.: Inhibition of angiotensin-converting enzyme by SQ 14,225 in conscious rabbits. Europ. J. Pharmacol. 46, 207-212 (1977)

8) Rubin, B., Laffan, R.J., Kotler, D.G., O'Keefe, E.H., DeMaio, D.A. and Goldberg, M.E.: SQ 14,225 (D-3-mercapto-2-D-methylpropanoyl-L-proline), a novel orally active inhibitor of angiotensin I-converting enzyme. J. Pharmacol. exp. Ther. 204, 271280 (1978)

9) SATOH, S. AND Zimmerman, B.G.: Influence of renin-angiotensin system on effect of prostaglandin synthesis inhibitors in renal vasculature. Circulation Res. 36-37 Supp. I, I-89-98 (1975)

10) Vander, A.J. And Geelhoed, G.W.: Inhibition of renin secretion by angiotensin II. Proc. Soc. exp. Biol. Med. 120, 399-403 (1965)

11) Ng, K.K.F.: Generation of kinins by renin. Prostaglandins, Peptides and Amines, Edited by Mantegazza, P. And Horton, E.W., p. 9-13, Academic Press, New York (1969) 